\title{
Milli Gelirin Vergi Yükü Üzerindeki Etkileri: ARDL Sınır Testi Yaklaşımı ile Türkiye Üzerine Bir İnceleme (1924-2014)
}

Ferdi ÇELIKAY, Department of Public Finance, Faculty of Economics and Administrative Sciences, Eskisehir Osmangazi University, Turkey; e-mail: fcelikay@ogu.edu.tr

\section{Effects of National Income on Tax Burden: An Investigation on Turkey with an ARDL Bounds Testing Approach (1924-2014)}

\begin{abstract}
The purpose of this study is to determine how the changes in GDP per capita, which is an indicator of economic development, affect the tax burden in the short and long term in Turkey. In this context, the study utilises data about GDP per capita and tax burden from 1924 to 2014 and employs the Autoregressive Distributed Lag (ARDL) bounds testing approach. Although many studies in the literature has been reached that there is a positive relationship between these variables, this study shows this interaction occurs only in the long term. In fact, the research finds a $1 \%$ increase in GDP per capita will bring about a $0.07 \%$ increase in tax burden in the long run. For short term there is a negative relationship between these variables but it is not statistically significant.
\end{abstract}

Keywords $\quad$ : Tax Potential, Tax Burden, ARDL-Error Correction Model, Tax Policy, Economic Growth.

JEL Classification Codes : $\quad$ H11, H20, H21, H24, H29.

$\ddot{\mathbf{O} z}$

$\mathrm{Bu}$ çalışmanın amacı, iktisadi gelişmişliğin bir göstergesi niteliğindeki kişi başına düşen GSYİH'da meydana gelecek değişikliklerin kısa ve uzun dönemde vergi yükü üzerinde ne gibi etkileri olacağını Türkiye özelinde saptayabilmektir. Bu bağlamda 1924-2014 zaman aralığında kişi başına düşen GSYİH ve vergi yükü değişkenleri esas alınarak ARDL sınır testi yaklaşımından yararlanılmıştır. Literatürde yer alan pek çok çalışmada değişkenler arasında pozitif yönlü bir ilişki olduğu bulgusuna ulaşılmışsa da çalışma sonucunda bu etkileşimin ancak uzun dönemde ortaya çıktığ tespit edilmiştir. Nitekim kişi başına düşen GSYİH'da meydana gelecek \%1'lik bir artış uzun dönemde vergi yükü üzerinde yaklaşı \%0,07 düzeyinde pozitif yönlü bir etki meydana getirmektedir. Kısa dönemde ise istatistiksel açıdan anlamlı olmamakla birlikte bu etkileşim ters yönlüdür.

Anahtar Sözcükler $\quad$ : Vergi Potansiyeli, Vergi Yükü, ARDL-Hata Düzeltme Modeli, Vergi Politikas1, Ekonomik Büyüme. 
Çelikay, F. (2017), “Milli Gelirin Vergi Yükü Üzerindeki Etkileri: ARDL Sınır Testi Yaklaşımı ile Türkiye Üzerine Bir İnceleme (1924-2014)", Sosyoekonomi, Vol. 25(32), 169-188.

\section{Giriş}

Mali bir araç niteliğindeki vergiler, kamu harcamalarının finansmanı sürecinde iktisadi ve sosyal pek çok bileşen üzerinde doğrudan ya da dolaylı etkilere sahiptir. Vergilerin ulusal, bölgesel, sektörel ya da kişisel etkilerini tespit edebilmek açısından ise literatürde kullanılan temel ölçütler arasında vergi yükü yer almaktadır. Genel olarak vergi yükü, belirli bir dönemde ödenen vergilerin esas alınan ölçeğe göre değişebilecek nitelikteki gelire oranı şeklinde tanımlanabilir. Bu bağlamda vergi yükü hesaplamaları özellikle gelir dağılımı politikaları, sektörel ve bölgesel teşvik tedbirleri, iktisadi büyüme sürecinin sürdürülebilirliği ve maliye politikasının etkinliği gibi başlıklarda önem arz etmektedir. Yine vergi sisteminin ve vergi yapısının inşası sürecinde de temel bir girdi olarak kullanılmaktadır. Ayrıca belirli bir döneme ilişkin bölgesel, sektörel ya da ulusal kapsamda hesaplanan vergi yükleri, politika belirleyicilere vizyon kazandırabilmekte, yeni bir verginin konulması, mevcut vergi bileşiminin düzenlenmesi ve çeşitli alanlara vergi harcamalarının yapılması gibi başlıklarda politika geliştirilmesini sağlayabilmektedir (Berksoy \& Demir, 2004: 516-518; Tekbaş \& Dökmen; 2007; 196-198). Kamu harcamalarının finansmanı açısından toplumu oluşturan bireylerin optimal vergi ödeyebilme gücü ise genel itibariyle vergi kapasitesi olarak betimlenmektedir. Vergi kapasitesi, mikro düzeyde mükellefin asgari ihtiyaçlarını giderebilmesi için gerekli olan minimum gelirinin üzerindeki artık değeri yansitırken, makro ölçekte ise tüm mükelleflerin vergi ödeme güçlerinin toplamını ifade etmektedir (Akdoğan, 2014: 187-188). Genel olarak kişi başına gelir düzeyi, gelir dağılımı, ekonominin dışa açıklığı, parasal ekonominin yaygınlaşması ve iktisadi hayatın yapısal dönüşümü gibi faktörler bir ülkedeki vergi kapasitesini belirleyen iktisadi bileşenler arasında siralanabilmektedir (Nadaroğlu, 1978: 287; Berksoy, 1984: 6; Uluatam, 1997: 319). Dolayısıyla ekonomik kalkınma ve büyümenin bir göstergesi olarak vatandaşların gelir düzeyinde yaşanacak bir artışın, vergi kapasitesinin ve vergi yükünün de olumlu bir doğrultuda etkilenmesini sağlayacağı belirtilebilir. Ne var ki vergi potansiyelini etkin şekilde kavrayan bir mali sistemin varlığı vergi yükünün optimal düzeyde gerçekleşmesi açısından vazgeçilemez bir faktördür. Bu husus, bir ülkenin vergilendirme kapasitesini ne ölçüde kullanabildiğiyle de doğrudan ilintilidir.

Bu çalıșmanın amacı Türkiye'de iktisadi kalkınma ve büyüme sürecinin nesnel bir göstergesi niteliğindeki kişi başına düşen GSYİH'da meydana gelecek değişikliklerin kısa ve uzun dönemde vergi yükü üzerinde ne gibi etkileri olacağını saptayabilmektir. Bu bağlamda 1924-2014 zaman aralığında kişi başına düşen GSYİH ve vergi yükü değişkenleri esas alınarak ARDL sınır testi yaklaşımından yararlanılmıştır. Literatürde yer alan pek çok çalışmada iki değiş̧ken arasında pozitif yönlü bir ilişki olduğu bulgusuna ulaşılmışsa da çalışma sonucunda bu etkileşimin ancak uzun dönemde ortaya çıktığı tespit edilmiştir. Kısa dönemde ise artan gelir beklenenin aksine vergi yükünü negatif doğrultuda etkilemektedir. $\mathrm{Bu}$ yönüyle çalışmada elde edilen ampirik bulguların literatüre de katkı sağlayacağı düşünülmektedir.

Çalışmanın izleyen bölümünde öncelikle vergi yükü, vergi yükünün temel belirleyicileri ve vergi yükü ile temel ekonomik değişkenler arasındaki ilişkileri esas alan teorik ve uygulamalı literatüre değinilmekte, daha sonra 1924-2014 yıllarını kapsayan 
dönemde vergi sisteminin yapısal dönüşümü değerlendirilmektedir. Üçüncü bölümde ise çalışmanın analiz sürecinde kullanılan ampirik yöntemin metodolojik arka planına yer verilmektedir. Dördüncü bölümde çalışmada kullanılan veri seti ele alınmakta ve yapılan analizler sonucunda elde edilen bulgular açıklanmaktadır. Son bölümde ise bir bütün olarak çalışmanın sonuçları tartışılmaktadır.

\section{Literatür İncelemesi}

Günümüz iktisadi koşullarında gerek gelişmiş ve gerekse gelişmekte olan ülkeler açısından bir ekonomik sistemin vergisel kapasitesini, vergi yükünü ve/veya vergi gayretini belirleyen pek çok bileşenin varlığından söz edilebilir. Bunlar içerisinde özellikle vergi sisteminin yapısı, vergi idaresinin etkinliği, kayıt dışı ekonominin varlığı, sosyal, ekonomik ve siyasi amaçlarla yapılan vergi harcamaları ve mükelleflerin vergiye gönüllü uyumu gibi hususlar ön plana çıkmaktadırı (Thorn, 1967; Berksoy, 1984; Nadaroğlu, 1978; Uluatam, 1997; Çelikkaya, 2002; Berksoy \& Demir, 2004; Ferhatoğlu, 2005; Çelikkaya, 2013; Akbey, 2014). Mali sistemin vergi performansı ise fiilen toplanan vergi hasılatı ile vergi kapasitesinin, yani potansiyel hasılatın karşılaştırılması sonrasında belirlenebilir. Mali sistemin fiilen sergilediği vergi performansı kolay bir şekilde ölçülebilmekle birlikte vergi potansiyeli ya da kapasitesinin ölçümünde literatürde farklı yaklaşımlar mevcuttur2 (Lotz \& Morss, 1967; Bahl, 1971; Truong \& Gash, 1979; Engen \& Skinner, 1992; Leibfritz \& Thornton \& Bibbee, 1997; Purohit, 2006; Dennis \& Moore \& Somerville, 2007; Kong \& Hoek, 2008; Nikola, 2015).

Nitekim Lotz ve Morss (1967), 72 ülkenin verilerini derleyerek gerçekleştirdikleri çalışmalarında kişi başına GSMH ile dışa açıklık düzeyinin vergi yükü ve vergi kapasitesi ile vergi gayretini pozitif yönde etkilediğini ve bu iki kavramın temel belirleyicisi olduğunu ifade etmişlerdir. Ancak kişi başına gelir ve ihracat ile ithalat hacmi gibi dışa açıklık göstergelerinin vergi yükü üzerinde herhangi bir etkisi olmadığını ya da mevcut etkileşimin çok zayıf olduğunu ortaya koyan çalışmalar da bulunmaktadır (Shin, 1969; Bahl, 1971). Bunun yanında Stotsky ve Asegedech (1997), Afrika ülkeleri için gerçekleştirdikleri çalışmalarında vergi kapasitesinin temel belirleyicilerini incelemişler, vergi gayreti ile bütçe dengesizliğinin giderilmesi bağlamında izlenen maliye politikaları arasında ciddi bir ilişki tespit etmişlerdir. 43 Afrika ülkesi örnekleminde gerçekleştirilen panel veri analizinde, tarım ve maden sektörünün büyüklüğü ile vergi gayreti arasında ters yönlü bir ilişki var iken, ihracat büyüklüğü ile kişi başına gelir değişkenlerinin ise vergi gayretini pozitif doğrultuda etkilediği de gözler önüne serilmiştir (Stotsky \& Asegedech, 1997). Benzer şekilde Eltony (2002), 16 Arap ülkesinin verilerini kullanarak gerçekleştirdiği panel veri analizinde kişi başına gelir ile tarım ve maden sektörlerinin büyüklüğü olmak üzere vergi gayretinin üç

I Literatürde vergi yükünün çeşitli yönlerini ve etkileşimlerini esas alan teorik ve ampirik pek çok çalışma mevcuttur. EK'de söz konusu çalışmalara ilişkin özet bilgiler sunulmuştur.

2 Detayl bilgi için bkz. Berksoy, Turgay (1984). Gelişmekte olan ülkelerde vergi kapasitesi ve vergi gayreti, Marmara Üniversitesi, Sosyal Bilimler Enstitüsü, Yayımlanmış Doktora Tezi, s. 13-42, Yayın No: 411. 
temel belirleyicisi olduğu sonucuna ulaşmıştır. Yine Kong ve Hoek (2008), 1984 ile 2004 yılları arasındaki dönemde, Çin özelinde yaptıkları çalışmalarında ekonomik yapı, vergi politikalarındaki değişiklikler ve vergi idaresinin etkinliği gibi faktörlerin dışsal olarak kabul edildiği takdirde, vergi gelirlerindeki artışın en önemli nedeninin GSYİH'daki artış olduğunu ortaya koymuşlardır. Ancak bahsedilen faktörlerin birinde ya da bir kaçında meydana gelen değişiklikler vergi hasılatında ya da vergi yükündeki artışın GSYİH'da meydana gelen artıştan daha fazla olmasına sebebiyet verebilmektedir (Kong \& Hoek, 2008).

Bunun yanında Cural ve Çevik (2015), 1924-2013 yılları arasındaki dönemde kalkınma ile vergi yapısı arasındaki ilişkileri Türkiye özelinde inceledikleri çalışmalarında, kişi başına GSYİH'nın çeşitli kategorilerdeki vergi türleri üzerinde var olan etkilerini ele almışlardır. Çalışmada elde edilen bulgulara göre kalkınma sürecinin, özellikle gelir üzerinden alınan vergiler, dolaylı karakteristiğe sahip mal ve hizmetler üzerinden alınan vergiler ile dış ticaret işlemlerinden alınan vergiler üzerinde istatistiksel olarak anlamlı ve olumlu bir etkisi vardır. Ayrıca parçalı regresyon analizi sonuçlarına göre kalkınma seviyesinin artması dolaysız vergileri başlangıçta daha hızlı artırırken ilerleyen aşamalarda ise etkisini kaybetmektedir (Cural \& Çevik, 2015: 148).

Kamu kesimince gerçekleştirilen harcamalar, toplanan gelirler ve/veya yapılan borçlanmalar aracılığıyla şekillendirilen politikaların milli gelir seviyesi ile ilişkilerini ele alan çalışmalar, genel olarak İçsel Büyüme Teorileri çerçevesinde şekillenmiştir. İçsel Büyüme Teorileri, iktisadi büyümenin kaynağı olarak teknolojik ilerlemeler (Romer, 1986; Grosman \& Helpman; 1989; Romer, 1990; Becsi \& Wang, 1997; Albelo, 1999), nüfus ve beşeri sermaye birikimi (Lucas, 1988; Becker \& Murphy \& Tamura, 1990) ve/veya kamu kesimince izlenen politikalar (Romer, 1986; Barro, 1991; Rebelo, 1991; Jones \& Manuelli \& Rossi, 1993) gibi ekonomik sistemin iç dinamiklerini referans almaktadır. Bu kapsamda, toplumsal gereksinimlerin finansmanı sürecinde mali bir araç olarak toplanan vergiler de ekonomik büyüme sürecinin en önemli belirleyicileri arasında konumlandırılabilir. Nitekim kamu kesimince gerçekleştirilen cari, yatırım ve transfer harcamalarının finansal bir karşılığ olan vergilerdeki bir birimlik artış, özellikle verimli alanlarda kullanılması sonrasında GSYİH'yı da artırmakta ve GSYİH'daki artış ise daha fazla vergi hasılatı elde edilmesine sebebiyet vermektedir. Gerçekten Vasiliauskaite ve Stankevicius (2009), 1995 ile 2007 yıllarını kapsayan döneme ait Avrupa Birliği üyesi ülkelerin vergi sistemleri ile ekonomik büyüme verilerini kullanarak yaptıkları çalışmalarında, iki değişken arasında pozitif yönlü ve güçlü bir korelasyon olduğunu tespit etmişlerdir. Bunun yanında Tiwari ve Mutascu (2013), ABD’nin 1947 ile 2009 yılları arasında çeyrek dönemlik vergi yükü ve GSYİH verilerini kullanarak gerçekleştirdikleri doğrusal olmayan Granger nedensellik analizi sonucunda da benzer bulgulara ulaşmıştır. Araştırmacılar, şahsi vergiler ile üretim ve ithalat üzerinden alınan vergilerden GSYİH'ya doğru tek yönlü nedensellik tespit etmişler, bir bütün olarak bakıldığında vergilerdeki değişimin GSYİH'da yaşanacak değişimlerin nedeni olduğunu belirtmişlerdir. Ortalama vergi oranları ile ekonomik büyüme arasındaki ilişkiyi 1964 ile 2007 yılları arasında çeyrek dönemlik verileri ele alarak inceleyen Karagianni, Pempetzoglou ve Saraidaris (2012) ise vergi yükünden ekonomik büyümeye doğru bir nedenselliğin olduğunu, dolayısıyla vergilendirme sürecinin bir politika aracı olarak 
kullanılabileceğini ileri sürmüşlerdir. Ekonomik büyümenin beraberinde getirdiği refah artışı, aynı şekilde ekonomik büyümeden vergi yüküne ve vergilerin yeniden dağılımına doğru da bir etkileşimi ortaya çıkarmaktadır (Karagianni \& Pempetzoglou \& Saraidaris, 2012).

Vergi sistemi, vergi yükü ve vergisel büyüklükler ile iktisadi büyüme arasındaki ilişkiyi Türkiye özelinde ele alan çalışmalar da literatürdeki öncül mahiyetteki incelemelerin sonuçlarını destekler niteliktedir. Örneğin Açıkgöz (2008)'ün, 1968 ile 2006 yılları arasındaki dönemi kapsayan bir zaman dilimde Türkiye özelinde yaptığı çalışmasında, vergi gelirleri ile vergi yapısının iktisadi büyüme üzerindeki etkileri nedensellik analizi ve etkitepki fonksiyonları ile incelenmiş, dolaysız vergi gelirlerinin GSYİH içerisindeki payı düşük ise daha yüksek bir büyüme oranı sağlanacağı yönünde bulgulara ulaşılmıştır. Bunun yanında düşük toplam vergi yükünün yüksek bir büyüme oranını sağlayacağı yönünde zayıf da olsa istatistiksel sonuçlar elde edilmiştir. Ayrıca çalışmada, ekonomik büyümenin vergilendirme süreci üzerinde kuvvetli derecede etkili olduğu sonucuna ulaşılmıştır (Açıkgöz, 2008). Temiz (2008) ise, Türkiye için 1960-2006 yıllarını kapsayan dönemde vergi gelirleri ile ekonomik büyüme arasındaki ilişkiyi eşbütünleşme ve hata düzeltme yöntemlerini kullanarak ele aldığ 1 çalışmasında, iki değişken arasında uzun dönemli ve çift yönlü bir ilişki olduğu sonucuna varmıştır. Yine Gül ve Kenar (2009), 1980 ile 2008 yıllarını kapsayan bir dönemde 27 AB üyesi ülke ile Türkiye'yi kapsayan örneklemde gerçekleştirdikleri panel eşütünleşme analizi sonucunda vergi gelirleri ile ekonomik büyüme arasında uzun dönemli bir ilişki olduğu sonucunu elde etmiştir.

Bunun yanında Ünlükaplan ve Arısoy (2011), Türkiye ekonomisinde 1968 ile 2006 dönemi için vergi kaması ve vergi yükünün iktisadi büyüme ile olan dinamik ilişkilerini ele aldıkları çalışmalarında, kısa dönemde iktisadi büyümeden vergi kamasına doğru nedensellik ilişkisi tespit etmişler, uzun dönemde ise iktisadi büyüme ile vergi kamasından vergi yüküne ve vergi kaması ile vergi yükünden iktisadi büyümeye doğru nedensellik bulgusuna ulaşmışlardır. Ayrıca Erdoğan, Topçu ve Bahar (2013), Türkiye'nin 1998 ile 2011 yılları arasında çeyrek dönemlik vergi gelirleri ile ekonomik büyüme verilerini kullanarak gerçekleştirdikleri eşbütünleşme ve nedensellik analizi sonucunda, dolaylı vergiler ile ekonomik büyüme arasında uzun dönemli bir ilişki saptamışlardır.

Vergi yükündeki artışın verimli başlıklarda kullanılmaması ise bir bütün olarak vergileri toplumdaki bireyler üzerinde bir külfet, ekonomik yapı üzerinde mali bir kayıp ve iktisadi büyüme sürecinde ise yavaşlatıcı bir unsur haline getirebilmektir. Nitekim Koester ve Kormendi (1989), Barro (1991), Engen ve Skinner (1992), Easterly ve Rebelo (1993) Slemrod ve Yitzhaki (1995), Leibfritz, Thornton ve Bibbee (1997) vergi yükü ile GSYİH arasında negatif yönlü bir ilişki olduğunu, vergi yükündeki bir artışın GSYİH üzerinde olumsuz yansımalar meydana getireceğini, bu yansımaların ekonomik büyümeyi frenleyeceğini, iktisadi durgunluğun ise nihai olarak vergi yükü üzerinde olumsuz etkileri olacağını ileri sürmüşlerdir. Benzer şekilde 21 OECD üyesi ülkenin vergi yapıları ve ekonomik büyüme verileri arasındaki ilişkiyi panel veri analizi yöntemiyle inceleyen Arnold (2008), vergi yükü ile ekonomik büyüme arasında ters yönlü bir ilişki olduğu bulgusuna ulaşmıştır. Ayrıca Kuştepeli ve Bilman (2009), 1975 ile 2004 yılları arasında vergilerin 
büyüme üzerindeki etkilerini eşbütünleşme analizi ile ele aldıkları çalışmalarında, toplam vergi yükü, gelir vergisi yükü ile mal ve hizmet vergisi yükü arttıkça uzun dönemde iktisadi büyümenin olumsuz bir şekilde etkilendiği sonucunu elde etmişlerdir. Bunun yanında Öztürk ve Ozansoy (2011), ücret gelirleri üzerindeki aşırı vergi yükünün yeni yatırımları engellediğini, kayıt dışı ekonomiyi genişlettiğini ve bu bağlamda ekonomik rekabet gücü ve istihdam artışını zayıflattığını belirtmektedirler. Hiç şüphesiz ki bu etkileşimin potansiyel vergi yükünün değişmesine de neden olacağı ileri sürülebilir. Mangır ve Ertuğrul (2012) ise Türkiye'de vergi yükü ve ekonomik büyüme arasındaki ilişkiyi 1988 ile 2011 yıllarını kapsayan dönem bağlamında incelemiş, uzun ve kısa dönemde vergi yükü ile GSYİH arasında istatistiksel olarak ters yönlü bir ilişki olduğu bulgusuna ulaşmışlardır. Bu çerçevede değerlendirilecek olur ise vergi yükünün ağırlı̆̆ı ve sistemin kompleks, adil olmayan yapısı gibi sübjektif ve objektif faktörlerin varlığı, bireylerin artan gelirlerini vergilendirmek istememe girişimlerinin altında yatan nedenleri ortaya çıkarabilmektedir (Demir, 2013). Böylesine bir sürecin ürünü olarak da vergi yükü ile ekonomik büyüme arasında ters yönlü ilişkinin ortaya çıkması son derece doğal karşılanabilir.

Gerek bu başlıkta değinilen ve gerekse EK'de yer alan çalışmalardan görüldüğü gibi, bir ülkenin ya da ekonomik sistemin vergi yükünü belirleyen pek çok etmenden söz etmek mümkündür. Farklı çalışmalar bu faktörler arasında GSYİH, iktisadi, mali ve kurumsal yapı, para politikalarının etkinliği ve parasallaşma süreci, kayıt dışı ekonomi, vergi sisteminin etkinliği, ekonominin dişa açıklığı, sosyal, ekonomik ve siyasi amaçlarla yapılan vergi harcamaları ve mükelleflerin vergi bilinci gibi faktörleri ön plana çıkarmaktadır. Çalışmanın incelediği temel problem ise Türkiye'de kişi başına düşen GSYİH'nın vergi yükü üzerinde kısa ve uzun dönemde nasıl, ne derecede ve hangi yönde etkileri olduğudur. Bahsedilen problem perspektifinde, "Kişi başına düşen GSYIH ile vergi yükü arasında dönemler itibariyle ve istatistiksel açıdan anlamlı bir ilişki vardır" şeklinde hipotez geliştirilmiştir. İzleyen bölümlerde öncelikle ele alınan dönem itibariyle vergi sisteminde yaşanan yapısal dönüşümler ile vergi yükünün gelişim trendi değerlendirilmekte, daha sonra ise araştırma hipotezinin sınanması sürecinde izlenen ampirik yöntemin metodolojik arka planına ve analiz sonrasında elde edilen bulgulara değinilmektedir.

\subsection{4-2014 Döneminde Vergi Sisteminin Yapısal Dönüşümü}

1924 ile 2014 dönemini kapsayan 90 yıllık zaman dilimi uygulamalı bir analiz için oldukça geniş bir aralığı içermektedir. Bu dönem dâhilinde Türk Vergi Sisteminde irili ufaklı, hukuki ve mali pek çok düzenleme yapılmış, iktisadi hayatın şekillenmesine sebebiyet vermiştir. Çalışmanın bu alt başlığında vergi yapısında gerçekleştirilen düzenlemeler tarihsel süreç itibariyle değerlendirilmektedir. Nihayetinde, her ne kadar analiz sürecinde dışsal kabul edilse de literatürde değinilen çeşitli çalışmalarda da gözlemlendiği gibi, vergi yükü ile milli gelir arasındaki ilişkiyi şekillendiren en önemli faktörlerden biri de mali sistemde yaşanan değişimlerdir. Aşağıdaki grafik, çalışmada ele alınan dönem itibariyle toplam, dolaylı ve dolaysız vergi yükünün gelişim seyrini yansitmaktadır. Tablo 1 ise vergi sisteminde yapılan mali düzenlemeleri sunmaktadır. 


\section{Grafik: 1}

\section{Türkiye'de Vergi Yükünün Gelişim Seyri (1924-2014)}

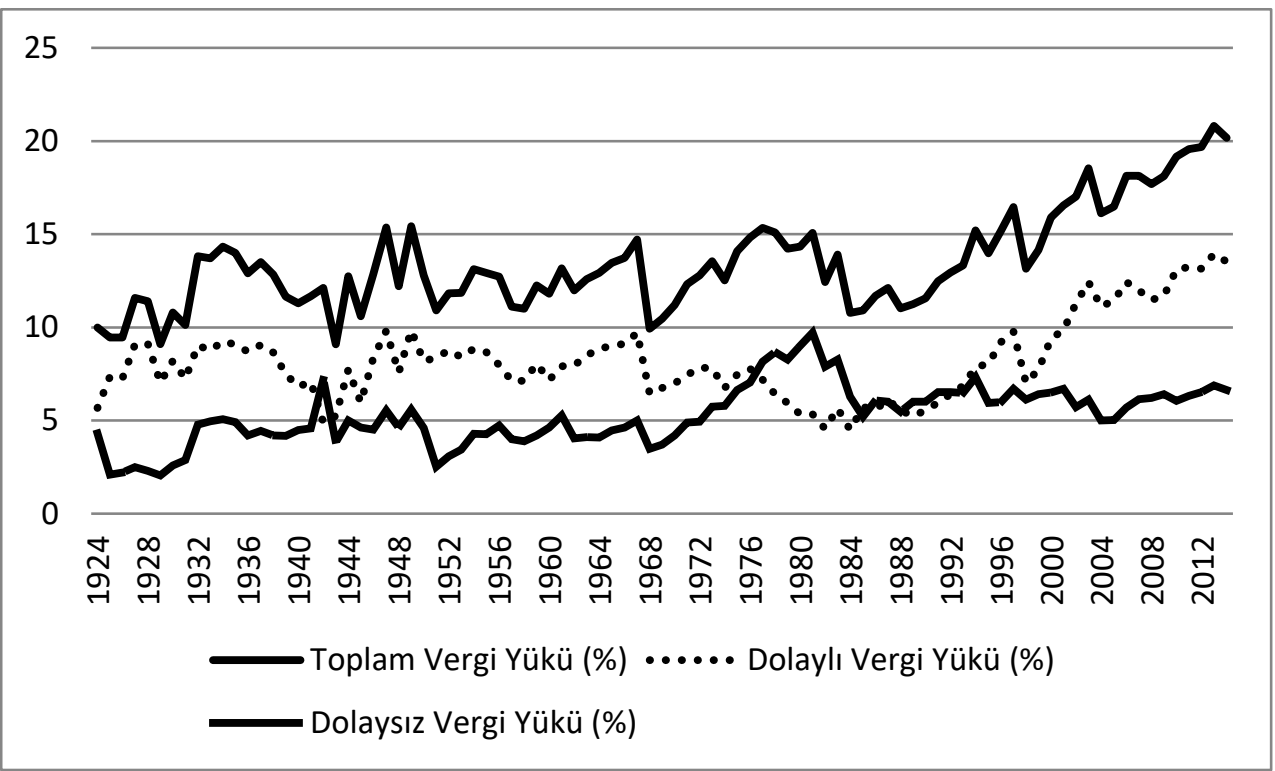

Cumhuriyetin kuruluşundan günümüze geçen süreçte yapılan bazı önemli düzenlemelere kronolojik olarak yer veren Tablo 1 ile Grafik 1 birlikte değerlendirildiğinde, özellikle 1925 yılında dolaysız bir mali gelir karakteristiğindeki Aşar Vergisi'nin kaldırılması ve doğan boşluğun 1926 yılında getirilen dolaylı vergilerle (Umumi İstihlak Vergisi ile Eğlence ve Hususi İstihlak Vergisi) telafi edilmek istenmesi nedeniyle, dolaysız vergi yükü azalırken dolaylı vergi yükünün ise arttı̆̆ı görülmektedir. Söz konusu zaman diliminde toplam vergi yükünün de dolaylı vergi yükündeki sıçrayışa bağlı olarak ciddi bir biçimde arttığ gözlemlenmektedir.

Grafik 1'de gözlemlenen bir diğer önemli kırılma 1930-1933 yılları arasındaki döneme denk gelmektedir. Özellikle Dünya Ekonomik Bunalımının olumsuz yansımalarını giderebilmek bağlamında 1931-32 yılında getirilen vergiler ve mali mevzuatta yapılan değişiklikler vergi yükünde artışa neden olmuştur. 1940'lı yıllarda ise bu kez savaş koşullarında getirilen olağanüstü vergilerin etkisiyle bir artış yaşanmıştır. Burada 1942 yılında Varlık Vergisi'nin uygulanması ile dolaysız vergi yükünde de bir sıçrama olduğu göze çarpmaktadır.

Bunun yanında 1949 yılında Kazanç Vergisi’nin kaldırılarak 1950 yılından itibaren yerine Gelir, Kurumlar ve Esnaf Vergilerinin yürürlüğe girmesi, dolaysız vergi yükü üzerinde kısa, orta ve uzun vadede etkiler meydana getirmiştir. Nitekim 1960 yılında 193 sayılı Gelir Vergisi Kanunu'nun yürürlüğe girmesi, Kurumlar Vergisi Kanunu'nda yapılan değişiklikler ve 1970 yılında yürürlüğe giren 1318 sayılı Finansman Kanunu ile getirilen 
yeni vergilerin de etkileriyle vergi yükü içerisinde dolaysız vergilerin daha baskın bir hal aldığı söylenebilir.

\section{Tablo: 1}

Yıl Yapılan Düzenlemeler

\section{Vergi Sisteminde Yapılan Düzenlemelerin Kronolojisi}

1925 Aşar Vergisi'nin kaldırılması

1926 Temettü Vergisi'nin kaldırılması, "Veraset ve İntikal Vergisi Kanunu”nun kabulü, "Kazanç Vergisi”, "Umumi İstihlak Vergisi” ile "Eğlence ve Hususi İstihlak Vergisi”nin yürürlüğe girmesi

1927 Umumi İstihlak Vergisi'nin kaldırılarak yerine Muamele Vergisi'nin konulması

1929 Gümrük Tarifesi ve İthalat Umumi Tarifesi Kanunu’nun yürürlüğe girmesi

1931 İktisadi Buhran Vergisi, Hayvanlar Vergisi, Bina Vergisi, Arazi Vergisi’nin yürürlüğe girmesi, 1927 yılında yürürlüğe giren Muamele Vergisi kapsamının daraltılması, Veraset ve İntikal Vergisi Kanunu'nda değișiklikler yapılmas

1932 Muvazene Vergisi'nin yürürlüğe girmesi

19341926 yılında konulan Kazanç Vergisi'nin kaldırılarak Yeni Kazanç Vergisi Kanunu’nun yürürlüğe girmesi, Tekel maddelerinden alınacak Savunma Vergisi'nin yürürlüğe girmesi

1936 Hava Kuvvetlerine Yardım Vergisi'nin yürürlüğe girmesi

1941 Ayni Muamele Vergisi'nin yürürlüğe girmesi

1942 Varlık Vergisi'nin yürürlüğe girmesi

1943 Varlık Vergisi'nin kaldırılması, Toprak Mahsulleri Vergisi'nin yürürlüğe girmesi

1946 Toprak Mahsulleri Vergisi'nin kaldırılması

1947 Ayni Muamele Vergisi'nin kaldırılması

1949 Kazanç Vergisi'nin kaldırılması, Gelir, Kurumlar ve Esnaf Vergisi Kanunlarının kabulü

1950 Gelir, Kurumlar ve Esnaf Vergisi Kanunlarının yürürlüğe girmesi,

1954 Yeni Gümrük Vergisi Kanunu’nun yürürlüğe girmesi

1955 Esnaf Vergisi Kanunu'nun kaldırılmas1

1957 Hususi Otomobil Vergisi Kanunu’nun kabulü, Gider Vergilerinin (İstihsal ve Hizmet) yürürlüğe girmesi

1959 Veraset ve İntikal Vergisi Kanunu'nun yeniden düzenlenmesi

193 sayılı Gelir Vergisi Kanunu’nun yürürlüğe girmesi (Gelir vergisi kapsamının tarım kesimini içerecek șekilde genișletilmesi, esnaf

1960 muaflığının daraltılması, götürü usul ile servet beyanı uygulamasının getirilmesi), Kurumlar Vergisi Kanunu'nda yapılan değişiklikler (sermaye şirketleri ile kooperatiflerde vergi oranının \%10'dan \%20'ye yükseltilmesi)

1963 Emlak Alım Vergisi’nin yürürlüğe girmesi

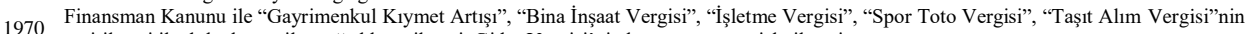

1970 getirilmesi ile dolaylı vergilere ağırlık verilmesi, Gider Vergisi'nin kapsamının genişletilmesi

1971 Gelir Vergisi'ne \%1 ilave edilerek Mali Denge Vergisi'nin uygulanması

1972 Emlak Vergisi Kanunu'nun yürürlüğe girmesi

1981 Gelir Vergisi Kanunu'nda değişiklikler yapılması (Tarife, istisna-muafiyet ve indirimler)

1985 Dâhilde Alınan İstihsal Vergisi, İthalden Alınan İstihsal Vergisi, Nakliyat Vergisi, PTT Hizmetleri Vergisi, İsletme Vergisi, Spor Toto

1985 Vergisi, İlan ve Reklam Hizmetleri Vergisi ile Şeker İstihlak Vergisi kaldırılarak yerine Katma Değer Vergisi Kanunu'nun yürürlüğe girmesi

1994 Ekonomik Denge Vergisi, Net Aktif Vergisi, Ek Gayrimenkul Vergisi, Ek Motorlu Taşıtlar Vergisi'nin yürürlüğe girmesi

1998 Gelir Vergisi Kanunu'nda götürü usul yerine basit usulün getirilmesi

2002 Özel Tüketim Vergisi’nin yürürlüğe girmesi, Katma Değer Vergisi oranlarında düzenleme yapılması

2004 Özel İletișim Vergisi ile Sans Oyunları Vergisi'nin yürürlüğe girmesi, Özel indirimin kaldırılması

5520 Sayılı Kurumlar Vergisi Kanunu'nun yürürlüğe girmesi, Gelir ve Kurumlar Vergisi oranlarında indirim yapılması, Gelir Vergisi'nde

2006 ücret gelirleriyle diğer gelir unsurları arasındaki \% 5 'lik oran farklılığının kaldırılması, ücret unsurunun tabi olduğu tarife ile diğer gelir unsurlarının tabi oldukları tarifelerin matrahları itibariyle farklılaștırılması

2008 Asgari geçim indirimi uygulamasının getirilmesi

1980'li yılların ortalarına gelindiğinde ise Katma Değer Vergisi'nin yürürlüğe girmesi ve gelir üzerinden alınan vergilerde yapılan düzenlemeler ile dolaylı vergilerin tekrar önem kazanmaya başladığı görülmektedir. Özellikle 1990’lı yılların ortalarında ve 2000'li yılların başında yaşanan iktisadi krizler sonrasında izlenen politikaların da etkisiyle dolaylı vergilerin vergi yükü içerisindeki belirleyici ve baskın rolünü pekiştirdiği söylenebilir. Ayrıca 2002 yılında Özel Tüketim Vergisi'nin yürürlüğe girmesi ve 2006 yılında gerek Kurumlar Vergisi'nde gerekse Gelir Vergisi'nde yapılan değişiklikler vergi yükünün gelişim seyrinin ve vergi karmasının yıllar itibariyle değişmesine neden olmuştur.

\section{3. Çalışmanın Metodolojisi}

Bu çalışmada, Türkiye'de kişi başına düşen GSYİH'nın vergi yükü üzerinde kısa ve uzun dönemler itibariyle nasıl etkileri olduğunu tespit edebilmek amaciyla, 1924 ile 2014 yıllarını kapsayan zaman dilimine ait veriler derlenmiş ve verilerin analizi sürecinde genel 
olarak ARDL sınır testi yaklaşımından yararlanılmıştır. Pesaran, Shin ve Smith (1996), Pesaran ve Smith (1998), Pesaran ve Shin (1999) ile Pesaran, Shin ve Smith (2001) tarafından geliştirilen ARDL yaklaşımının en önemli belirleyici özelliği, klasik eşbütünleşme testlerinin aksine farklı dereceden eşbütünleşik ilişki içerisinde olan değişkenlerin analizine imkân tanımasından ileri gelmektedir. Ayrıca Kısıtsız Hata Düzeltme Modeli (KHDM) olarak da anılan ARDL yaklaşımı, en küçük kareler yöntemine dayanmakta ve dar bir örnekleme sahip çalışmalarda kullanılabilmektedir. Bu yöntem, incelenen modelin kısa ve uzun dönemli bileşenlerinin otokorelasyon problemi göz önüne alınarak tahmin edilebilmesini de sağlamaktadır. Nitekim LM testi ile tahmin edilen modelin bünyesinde otokorelasyon problemi barındırıp barındırmadığı belirlenebilmektedir. Değişkenler arasında eşbütünleşik bir ilişki olup olmadığına ise Wald testi ile karar verilmektedir. Bu testin boş hipotezi "ele alınan değişkenler arasında eşbütünleşik ilişki yoktur" şeklinde olup, test ile gerek kısa dönem ve gerekse uzun dönem parametreleri arasındaki ilişki sınanmaktadır. ARDL yaklaşımı ile tahmin edilen modelin durağanlığı ve ele alınan veriler açısından yapısal bir kırılma olup olmadığı ise CUSUM testi tespit edilebilmektedir.

Çalışmada kişi başına düşen GSYİH'nın vergi yükü üzerindeki etkilerini belirleyebilmek amacıyla ARDL yaklaşımı perspektifinde kurulan temel model:

$$
\begin{aligned}
& \Delta Y_{t}=\alpha_{0}+\sum_{i=1}^{p} \alpha_{1 i} \Delta Y_{t-i}+\sum_{i=0}^{q} \alpha_{2 i} \Delta X_{1 t-i}+\cdots+\sum_{i=0}^{q} \alpha_{k i} \Delta X_{k t-i}+\beta_{1} Y_{t-1}+\beta_{2} X_{1 t-1}+ \\
& \cdots+\beta_{k} Y_{k t-1}+\varepsilon_{t}
\end{aligned}
$$

şeklindedir. Burada Y ve X, sırasıyla modeldeki bağımlı ve bağımsız değişkenleri, $\Delta$ her bir değişkene uygulanan birinci fark işlemini, $\alpha_{0}$ sabit terimi ve $\varepsilon_{t}$ ise hata terimini göstermektedir. (1) nolu denklemden görülebildiği gibi temel modelde açıklayıcı değişkenlerin farkları ile söz konusu değişkenlerin birinci dereceden gecikmeli değerleri olmak üzere değişkenler iki grupta toplanmaktadır. Analiz sürecinde öncelikle alternatif gecikme uzunlukları ile tahminler gerçekleştirilerek Akaike ve Schwarz Bilgi Kriterleri (AIC ve SIC) aracılığıyla en uygun gecikme uzunluğuna sahip model tespit edilmektedir. En uygun gecikme uzunluğu belirlendikten sonra (1) nolu eşitlik en küçük kareler yöntemi ile tahmin edilerek değişkenler arasındaki uzun dönemli eşbütünleşik ilişkinin varlığ 1 "Wald Testi" ile irdelenmektedir. Dolayısıyla (1) nolu eşitlikteki modelde yer alan gecikmeli değere sahip değişkenlerin uzun dönemdeki katsayılarını sıfıra eşitleyen $\mathrm{H}_{0}$ hipotezi $\left(\beta_{1}=\beta_{2}=0\right)$ ile katsayıların 0'a eşit olmadığını ileri süren alternatif hipotez $\left(H_{1}=>\beta_{1} \neq \beta_{2} \neq 0\right)$ test edilmektedir. Bu test sonucunda elde edilen F değeri Pesaran, Shin ve Smith (2001) tarafından oluşturulan asimtotik alt ve üst sınır değerleri ile mukayese edilmektedir. Şayet "Wald Testi" sonucunda hesaplanan F değeri alt sınırın aşağısında ise $\mathrm{H}_{0}$ hipotezi reddedilemeyecek iken, hesaplanan değer üst sınırın üzerinde ise boş hipotez reddedilebilecek, yani değişkenler arasında uzun dönemli eşbütünleşik bir ilişki olduğu 
bulgusuna ulaşılacaktır3. Bu bağlamda aralarında eşbütünleşik ilişki bulunan değişkenlerin uzun dönem ARDL modeli:

$$
Y_{t}=\alpha_{0}+\sum_{i=1}^{p} \alpha_{1 i} Y_{t-i}+\sum_{i=0}^{q} \alpha_{2 i} X_{1 t-i}+\cdots+\sum_{i=0}^{q} \alpha_{k i} X_{k t-i}+\varepsilon_{t}
$$

şeklindedir. Değişkenler arasındaki kısa dönemli ilişkiler ile uzun dönem ARDL modelinden elde edilen hata düzeltme teriminin etkilerini gösteren Hata Düzeltme Modeli ise:

$$
\Delta Y_{t}=\alpha_{0}+\sum_{i=1}^{p} \alpha_{1 i} \Delta Y_{t-i}+\sum_{i=0}^{q} \alpha_{2 i} \Delta X_{1 t-i}+\cdots+\sum_{i=0}^{q} \alpha_{k i} \Delta X_{k t-i}+\theta E C M_{t-1}+\varepsilon_{t}
$$

ile formüle edilebilir. Burada $\alpha_{1 i}, \alpha_{2 i}$ ve $\alpha_{k i}$ modelde yer alan değişkenlerin kısa dönem katsayıları, $\theta$ ise kısa dönemde ortaya çıkacak dengeden sapmanın uzun dönemde hangi oranda düzeltilebileceğini gösteren hata düzeltme terimi katsayısıdır4.

Çalışmada "Kişi başına düşen GSYİH ile vergi yükü arasında dönemler itibariyle ve istatistiksel açıdan anlamlı bir ilişki vardır” şeklinde geliştirilen hipotez:

Vergi Yükü = f (Kişi başına düşen GSYİH, diğer faktörler)

fonksiyonel ilişkisi ile formüle edilmiş olup, söz konusu hipotezi test edebilmek için iki adet ekonometrik model oluşsturulmuştur. Bunlar:

$$
\begin{aligned}
& \text { Model 1: } \text { Logvyt }_{t}=\beta_{0}+\operatorname{Loggsyih}_{(\mathrm{kb}) t}+u_{t} \\
& \text { Model 2: } \text { Logvyg }_{t}=\beta_{0}+\operatorname{Loggsyih}_{(k b) t}+u_{t}
\end{aligned}
$$

şeklindedir. Çalışmanın ampirik kısmında, (5) ve (6) nolu eşitliklerdeki temel modellere yukarıda belirtilen analiz süreci adım adım işlenmiş olup, analiz sürecinde elde edilen bulgulara bir sonraki başlıkta yer verilmektedir.

\section{Veriler ve Ampirik Bulgular}

Çalışmada 1924-2014 yıllarına ait cari fiyatlarla GSYİH, cari fiyatlarla tahmini genel bütçe vergi gelirleri, cari fiyatlarla gerçekleşen genel bütçe vergi gelirleri ve kişi başına düşen GSYİH (91 y1llık zaman dilimini kapsayan analiz sürecinde özellikle paranın satın alma gücünde meydana gelen değişikliklerin yapılan tahminleri olumsuz etkilemesini ve hatalı sonuçlar elde edilmesini önleyebilmek maksadıyla seri Dolar bazında işleme

3 Pesaran, Shin ve Smith (2001) tarafindan belirlenen alt ve üst sınır değerleri arasında kalan alan belirsizlik ya da kararsızlık bölgesidir. Wald testi istatistiği bu alan üzerine denk geliyorsa değişkenler arasında eşbütünleşme olup olmadığına dair bir sonuca ulaşılamamaktadır.

4 Bu terim değişkenler arasındaki uzun dönemli ilişkilerin sınandı̆̆ (2) nolu formülden türetilen modele ait hata terimlerinin bir gecikmeli değeridir. 
alınmıştır) verileri kullanılmıştırs. Analiz sürecinde vergi yükü değişkenini elde edebilmek için giriş ve literatür kısmında da teorik olarak değinildiği üzere, yıllar itibariyle cari fiyatlarla tahmini ve gerçekleşen genel bütçe vergi gelirlerinin cari fiyatlarla GSYİH'ya oranı alınmıştır. Kullanılan verilere ilişkin özet bilgiler Tablo 2'de yer almaktadır.

Tablo: 2

\section{Çalıșmada Kullanılan Veriler}

\begin{tabular}{lll}
\hline Değişkenin Türü & Kodu & Açıklaması \\
\hline & Logvyt & Tahmini genel bütçe vergi gelirlerinin gayri safi yurt içi hasıla içerisindeki \% payının logaritması \\
Bağımlı Değişkenler & &
\end{tabular}

Logvyg Gerçekleşen genel bütçe vergi gelirlerinin gayri safi yurt içi hasıla içerisindeki \% payının logaritması

Bağımsız Değişken $\quad$ Loggsyih $_{(\mathrm{kb})} \quad$ Kişi başına düşen GSYİH'nın logaritması (Dolar)

Değişkenler arasındaki ilişkileri ARDL sınır testi ile belirlenmeden önce, yıllık frekanstaki verilerin durağanlıkları analiz edilmiştir. Nihayetinde Pesaran, Shin ve Smith (2001) tarafından geliştirilen Wald-F istatistiği, değişkenlerin I(0) ve/veya I(1) düzeyinde durağan hale gelmeleri koşuluyla hesaplanabilmektedir. Verilerin hangi düzeyde durağan hale geldiklerini tespit edebilmek amacıyla boş hipotezi "ele alınan serilerde birim kök vardır" olan Genişletilmiş Dickey-Fuller (Augmented Dickey-Fuller (ADF)) ile PhillipsPerron (PP) birim kök testleri yapılmıştır. Test sonuçları Tablo 3'de özet halde verilmektedir.

Tablo: 3

Birim Kök Testleri Sonuçları

\begin{tabular}{|c|c|c|c|c|c|}
\hline & \multirow[b]{2}{*}{ Değişkenler } & \multicolumn{2}{|c|}{$\mathrm{ADF}$} & \multicolumn{2}{|c|}{ PP } \\
\hline & & Sabitli & Sabitli Trendli & Sabitli & Sabitli Trendli \\
\hline & Logvyt & $-0,604471$ & $-2,099192$ & $-3,161732^{b}$ & $-4,840420^{a}$ \\
\hline \multirow[t]{3}{*}{$\mathrm{I}(0)$} & Logvyg & -0.848272 & -1.210067 & $-2.646565^{\mathrm{c}}$ & $-4.419490^{\mathrm{a}}$ \\
\hline & $\operatorname{Loggsyih}_{(\mathrm{kb})}$ & $-0,340298$ & $-3,032268$ & $-0,335767$ & $-3,326696^{\mathrm{c}}$ \\
\hline & Logvyt & $-13,26119^{\mathrm{a}}$ & $-13,18142^{a}$ & $-16,81615^{a}$ & - \\
\hline \multirow[t]{2}{*}{ I(1) } & Logvyg & $-14.27785^{\mathrm{a}}$ & $-14.20164^{\mathrm{a}}$ & $-15.48471^{\mathrm{a}}$ & - \\
\hline & $\operatorname{Loggsyih}_{(\mathrm{kb})}$ & $-7,583250^{\mathrm{a}}$ & $-7,558520^{\mathrm{a}}$ & $-7,547456^{a}$ & $-7,456535^{\mathrm{a}}$ \\
\hline
\end{tabular}

${ }^{*}$ Tabloda (a) ile işaretlenen katsayının $p$ değeri \%1, (b) ile \%5 ve (c) ile \%10 düzeyinde istatistiksel olarak anlamlıdır.

Kaynak: Yazarm hesaplamalarl.

Tablo 3'de yer alan birim kök testi sonuçlarına göre tüm değişkenler I(1) düzeyinde durağan hale gelmektedir. Üç değişkenin de Pesaran, Shin ve Smith (2001) tarafindan geliştirilen Wald-F istatistiğine uygun olduğu tespit edildikten sonra, kişi başına düşen GSYIHH'nın değişik vergi yükü hesaplamaları üzerindeki kısa ve uzun dönemli etkilerini belirleyebilmek üzere bağımlı değişkenleri farklı olan (5) ve (6) nolu modeller için ARDL

5 Çalışmada kullanılan veriler TüIKK, Kalkınma Bakanlı̆̆l, Bütçe ve Mali Kontrol Genel Müdürlüğü ve Muhasebat Genel Müdürlüğ̈̈'nün yayımladı̆̆ı kaynaklardan derlenmiştir. 
sınır testi uygulaması gerçekleştirilmiştir. Bu bağlamda öncelikle, her bir modeldeki en uygun gecikme uzunluğu belirlenmiştir. Schwarz Bayesian ve Akaike Bilgi Kriterlerine göre iki modelde de ARDL $(1,1)$ tahmincisi en uygun gecikme uzunluğuna sahip tahminci olup, sonuçlar Tablo 4'te yer almaktadır.

Tablo 4'ün alt kısmındaki Tanı Testleri Sonuçlarına göre ARDL $(1,1)$ perspektifinde en küçük kareler yöntemiyle tahmin edilen modellerin hata terimlerinin normal dağıldığ 1 (p değeri \% 1 olarak esas alınmıştır), ayrıca otokorelasyon, değişen varyans ve tanımlama hatası problemlerini barındırmadıkları görülmektedir. Buradan yola çıkılarak kişi başına düşen GSYİH ile tahmini ve gerçekleşen vergi yükü değişkenleri arasında uzun dönemli eşbütünleşik bir ilişki olup olmadığı ARDL sınır testi (Wald Testi) yaklaşımı ile belirlenmiştir. Tablo 5 farklı modellerdeki değişkenler arasındaki eşbütünleşik ilişkinin varlığını Pesaran, Shin ve Smith (2001) tarafından belirlenen alt ve üst sınır değerlerine göre sınayan Wald Testi sonuçlarına yer vermektedir.

\section{Tablo: 4}

\section{ARDL (1,1) Tahmincisi Genel Sonuçları}

\begin{tabular}{|c|c|c|}
\hline & Model 1 & Model 2 \\
\hline & Bağımlı Değişken: $\Delta$ logvyt & Bağımlı Değişken: $\Delta$ logvyg \\
\hline C (Sabit) & $\begin{array}{r}0,865086^{\mathrm{a}} \\
{[0,214152]} \\
(4,039595)\end{array}$ & $\begin{array}{r}0,578463^{\mathrm{a}} \\
{[0,197689]} \\
(2,926131)\end{array}$ \\
\hline$\Delta \operatorname{logvyt}(-1)$ & $\begin{array}{r}-0,092012 \\
{[0,110290]} \\
(-0,834275)\end{array}$ & \\
\hline$\Delta \log v y g(-1)$ & & $\begin{array}{c}-0,303745^{a} \\
{[0,115137]} \\
(-2,638116)\end{array}$ \\
\hline$\Delta \operatorname{loggsyih}(\mathrm{kb})(-1)$ & $\begin{array}{r}-0,024520 \\
{[0,080298]} \\
(-0,305358)\end{array}$ & $\begin{array}{r}-0,076682 \\
{[0,063319]} \\
(-1,211040)\end{array}$ \\
\hline $\log v y t(-1)$ & $\begin{array}{c}-0,416354^{a} \\
{[0,096934]} \\
(-4,295226)\end{array}$ & \\
\hline $\log v y g(-1)$ & & $\begin{array}{r}-0,277728^{\mathrm{a}} \\
{[0,090588]} \\
(-3,065838)\end{array}$ \\
\hline $\operatorname{loggsyih}_{(\mathrm{kb})}(-1)$ & $\begin{array}{r}0,033708^{\mathrm{a}} \\
{[0,011045]} \\
(3,051818)\end{array}$ & $\begin{array}{r}0,023936^{b} \\
{[0,009561]} \\
(2,503580)\end{array}$ \\
\hline $\mathrm{R}^{2}$ & 0,253012 & 0,257527 \\
\hline $\begin{array}{r}\text { F-İstatistiği } \\
\text { Durbin-Watson İstatistiği }\end{array}$ & $\begin{array}{r}7,112886^{\mathrm{a}} \\
1,934304 \\
\end{array}$ & $\begin{array}{r}7,283851^{\mathrm{a}} \\
2,027990 \\
\end{array}$ \\
\hline \multicolumn{3}{|l|}{ Tanı Testlerine Îliskin Sonuclar } \\
\hline Jargue-Bera Testi (Normallik) & 4,563260 & $9,069197^{\mathrm{b}}$ \\
\hline LM Testi (Otokorelasyon) & 1,153347 & 0,977746 \\
\hline Harwey Testi (Değişen Varyans) & 0,660624 & 1,169725 \\
\hline Ramsey RESET Testi (Fonksiyonel Form) & 1,157342 & 0,371906 \\
\hline
\end{tabular}

${ }^{*}$ Tabloda (a) ile işaretlenen katsayının $p$ değeri \%1 ve (b) ile \%5 düzeyinde istatistiksel olarak anlamlıdır.

Kaynak: Yazarın hesaplamalart.

Tablo: 5

Wald Testi Sonucu ve Sınır Değerleri

\begin{tabular}{lr}
\hline & Wald Testi Sonucunda Hesaplanan F-İstatistik Değeri \\
\cline { 2 - 3 } Model 1 & $9,366048^{\mathrm{a}}$ \\
Model 2 & ${ }^{*}$ Tabloda (a) ile işaretlenen katsayının p değeri \%1 ve (b) ile \%5 düzeyinde istatistiksel olarak anlamlıdır.
\end{tabular}

Tablo 5'ten görüldüğü üzere hesaplanan F-İstatistik değerine göre değişkenler arasında eşbütünleşik bir ilişki olmadığına ilişskin boş hipotez Model 1 için \%1 ve Model 2 
için ise \%5 anlam düzeyinde reddedilmektedir. Bu bağlamda kişi başına düşen GSYİH ile tahmini ve gerçekleşen vergi yükü değişkenleri arasında uzun dönemde eşbütünleşik bir ilişki olduğu sonucuna ulaşılabilir. İki modele ilişkin uzun dönem katsayıları Tablo 6’te yer almaktadir.

Tablo: 6

ARDL (1,1) Yaklaşımı ile Elde Edilen Uzun Dönem Katsayı Tahminleri

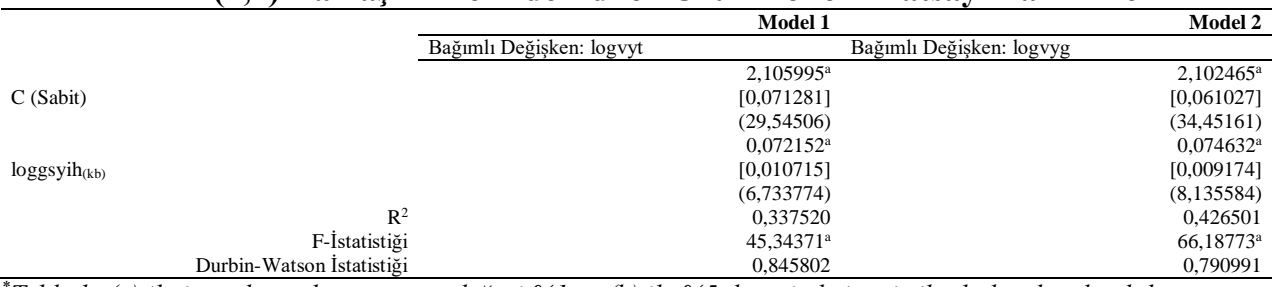

${ }^{*}$ Tabloda (a) ile işaretlenen katsayının p değeri \%1 ve (b) ile \%5 düzeyinde istatistiksel olarak anlamlıdır.

Kaynak: Yazarın hesaplamalart.

Tablo 6'daki sonuçlar kişi başına düşen GSYİH değişkenine ait katsayının iki model için de pozitif ve \%1 düzeyinde istatistiksel olarak anlamlı olduğunu göstermektedir. Yani kişi başına düşen GSYİH'da meydana gelecek \%1'lik bir artış her iki model birlikte dikkate alındığında uzun dönemde vergi yükünde yaklaşık \%0,07'lik bir artışa neden olmaktadır. Bu sonuç Türkiye'de, kişi başına düşen GSYİH'da meydana gelecek artışın uzun dönemde vergi yükü üzerinde olumlu etkileri olduğunu gözler önüne sermektedir. Değişkenler arasındaki uzun dönemli ilişkinin analiz sonuçları esas alınarak türetilen ve modellerde yer alan değiş̧kenler arasındaki kısa dönem ilişkilerini gösteren ARDL $(1,1)$ hata düzeltme modeli sonuçları Tablo 7'de yer almaktadır.

İki modeldeki değişkenler arasında kısa dönem ilişkisi hata düzeltme modeli ile elde edilmiş olup, Tablo 7'de kısa dönem ARDL $(1,1)$ tahmincisinde Model 1 ve Model 2 için hata düzelme katsayısının \%1 düzeyinde istatistiksel olarak anlamlı olduğu görülmektedir. Buna göre, baz bir dönemde meydana gelecek iktisadi dengesizliklerin Model 1'e göre yaklaşık \%42'si, Model 2'ye göre ise yaklaşık \%28'i bir sonraki yıl içerisinde düzelmekte ve değişkenlerin uzun dönem dengesine yakınsamasını sağlamaktadır. Ne var ki kişi başına düşen GSYİH'nın gecikmeli değerinin kısa dönemde bağımlı değişkenler üzerinde istatistiksel açıdan anlamlı bir etkisi bulunmamaktadır. Sadece Model 2'de gerçekleşen vergi yükünün gecikmeli değerinin gerçekleşen vergi yükü bağımlı değiş̧kenini istatistiksel açıdan $\% 5$ düzeyinde anlamlı ve negatif yönde etkilediği görülmektedir. Burada özellikle kişi başına düşen GSYİH'nın kısa dönem katsayısının her iki modelde de negatif olması ise ilginçtir. Her ne kadar istatistiksel açıdan anlamlı olmasa da bu sonuç kişi başına düşen GSYİH'da meydana gelen artışların kısa dönemde beklendiğinin aksine vergi yükünü artırmadığını tam tersine azalttığını yansıtmaktadır. Bu sonucun özellikle vergi sisteminin yapısından ve artan geliri hızlı bir şekilde kavrayacak esnekliğe sahip olmamasından kaynaklanan kronik problemlerin bir belirleyicisi olduğu ileri sürülebilir. 


\section{Tablo: 7 \\ Vergi Yükü ile Kişi Başına GSYİH Arasındaki Kısa Dönemli İlişki (ARDL (1,1) Hata Düzeltme Modeli) Sonuçları}

\begin{tabular}{|c|c|c|}
\hline & Model 1 & Model 2 \\
\hline & Bağımlı Değişken: $\Delta$ logvyt & Bağımlı Değişken: $\Delta \operatorname{logvyg}$ \\
\hline \multirow{4}{*}{ C (Sabit) } & 0,011595 & 0,014986 \\
\hline & {$[0,014772]$} & {$[0,012008]$} \\
\hline & $(0,784951)$ & $(1,248032)$ \\
\hline & $-0,088153$ & \\
\hline \multirow[t]{3}{*}{$\Delta \operatorname{logvyt}(-1)$} & {$[0,109372]$} & - \\
\hline & $(-0,805989)$ & \\
\hline & & $\begin{array}{l}-0,300105^{\mathrm{b}} \\
{[0,114319]}\end{array}$ \\
\hline \multirow{2}{*}{$\Delta \operatorname{logvyg}(-1)$} & & $(-2,625154)$ \\
\hline & $-0,020447$ & $-0,073256$ \\
\hline \multirow{3}{*}{$\Delta \operatorname{loggsyih}($ kb) $(-1)$} & {$[0,079323]$} & {$[0,062572]$} \\
\hline & $(-0,257767)$ & $(-1,170742)$ \\
\hline & $-0,417416^{\mathrm{a}}$ & $-0,279609^{\mathrm{a}}$ \\
\hline \multirow[t]{2}{*}{ Hata Düzeltme Terimi " $\theta$ " (-1) } & {$[0,096430]$} & {$[0,090069]$} \\
\hline & $(-4,328668)$ & $(-3,104391)$ \\
\hline $\mathrm{R}^{2}$ & 0,251444 & 0,255710 \\
\hline F-İstatistiği & $9,517308^{\mathrm{a}}$ & $9,734269^{\mathrm{a}}$ \\
\hline Durbin-Watson İstatistiği & 1,934842 & 2,025656 \\
\hline \multicolumn{3}{|l|}{ Tan Testlerine Íliskin Sonuclar } \\
\hline Jargue-Bera Testi (Normallik) & 5,097466 & 9,845111 \\
\hline & 1,040014 & 1,060497 \\
\hline Harwey Testi (Değişen Varyans) & 0,309248 & 0,868261 \\
\hline Ramsey RESET Testi (Fonksiyonel Form) & 1,186913 & 0,321539 \\
\hline
\end{tabular}

${ }^{*}$ Tabloda (a) ile işaretlenen katsayının p değeri \%1 ve (b) ile \%5 düzeyinde istatistiksel olarak anlamlıdır.

Kaynak: Yazarin hesaplamalart.

Son olarak tahmin edilen ARDL(1,1) hata düzeltme modelinin tutarlı olup olmadiğg, yapısal değişmelerin test edilmesini sağlayan CUSUM testi ile sınanmıştır. Grafik 2'de yer alan CUSUM testi sonuçları görseli, sürekli çizgi ile sembolize edilen model tahminlerinin kesikli çizgilerle belirlenen ve $\% 5$ anlam düzeyinde modellerin durağanlığını sınayan sınırları geçmediğini, dolayısıyla iki modelin de ele alınan dönemde tutarlı olduğunu göstermektedir.

\section{Grafik: 2}

\section{CUSUM Testi Sonuçları}

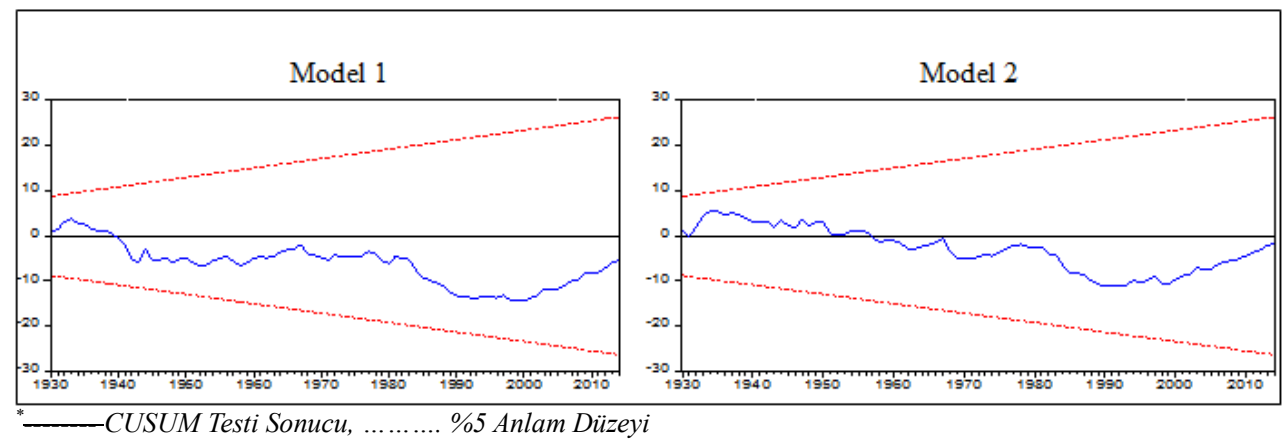




\section{Sonuç}

Vergi kapasitesi, bir ülkenin vergilendirilebilir ekonomik potansiyelini gözler önüne koymakta ve optimal düzeyde toplanabilecek vergi hasılatını yansıtmaktadır. Toplumsal ihtiyaçların karşılanması ve sosyal refah düzeyinin artırılabilmesi açısından ise vergi kapasitesinin tam olarak kullanabilmesi son derece önemlidir. Literatürde özellikle vergi sisteminin yapısı, kayıt dışı ekonominin yaygınlığ 1 ve vergi idaresinin etkinliği gibi hususlar ile iktisadi büyüme ve kalkınma süreci gibi temel ekonomik değişkenlerin vergi hasılatını, dolayısıyla da vergi yükünü doğrudan ya da dolaylı bir şekilde etkilediğine ilişkin değerlendirmeler ve bulgular yer almaktadır.

Bu çalışmada, Türkiye'de GSYİH'da meydana gelen değişikliklerin kısa ve uzun dönemde vergi yükü üzerinde ne gibi etkileri olduğu ARDL sınır testi yaklaşımı ile incelenmiştir. Çalışmada elde edilen bulgulara göre uzun dönemde kişi başına düşen GSYİH ile vergi yükü arasında istatistiksel açıdan anlamlı ve pozitif yönlü bir ilişki bulunmaktadır. Nitekim kişi başına düşen GSYİH'da meydana gelecek \%1'lik bir artış vergi yükünü yaklaşı1 \%0,07 oranında olumlu yönde etkilemektedir. Bu sonuç literatürdeki bulguları da desteklemektedir. Ancak hata düzeltme modeli ile tahmin edilen kısa dönem ilişkisine göre iki değişken arasında istatistiksel açıdan anlamlı bir ilişki bulunmamakla birlikte, kişi başına düşen GSYİH'da meydana gelecek bir artışın vergi yükünü artırmadığı, tam tersine negatif yönde etkilediği görülmektedir. Ayrıca kısa dönemde meydana gelecek iktisadi şokların etkileri ilk yılda nispeten yavaş bir hızla dengeye yakınsamaktadır. Özellikle vergi sisteminin artan geliri hızlı şekilde kavrayabilecek esnek bir dokuya sahip olmaması, bu şekildeki bir sonucun en önemli nedeni olarak değerlendirilebilir. Analiz sürecinde 90 yıllık zaman diliminde gerçekleştirilen reformların, iktisadi krizlerin ve nihayet literatürde değinilen diğer bileşenlerin dışsal kabul edilmesi çalışmanın en önemli kısıtını oluşturmaktadır. Bu bağlamda gelecek çalışmalarda bahsedilen her bir unsuru da içeren modeller geliştirilebilir. Yine iki değişken arasındaki etkileşimin varlığı ve yönü farklı gelişmişlik seviyesine sahip ülkeler açısından ele alınarak vergi yükü ve vergi kapasitesinin kullanımına yönelik önemli bulgular elde edilebileceği düşünülmektedir.

Çalışmada elde edilen sonuçlar, özellikle 1990'lı yıllara kadar dalgalı bir seyir izleyen, sonrasında ise bir artış trendi takip eden vergi yükündeki değişimlerde, ekonomik büyüme ve kalkınmanın nicel bir göstergesi mahiyetindeki “milli gelir artışı”nın belirleyici bir bileşen olduğunu gözler önüne sermektedir. Teoriye göre gelir ve servet üzerinden alınan ve dolaysız bir karakteristiğe sahip olan vergilerin, milli gelirdeki artışı mali anlamda tam olarak kavraması beklenmektedir. Dolayısıyla bu artışın gelir üzerinden alınan vergilerin artan geliri daha iyi kavramasından kaynaklandığı düşünülebilir. Ancak Grafik 1'de yer alan görgül sonuçlar Türkiye koşullarında, her ne kadar belirli zaman aralıklarında yapılan vergi reformlarının da etkisiyle dönemsel bir artış gösterse de, dolaysız vergilerin uzun vadede milli gelir artışını tam olarak kavrayamadığını ortaya koymaktadır. Buna karşılık, mal ve hizmetler ile dış ticaret işlemleri üzerinden alınan dolaylı vergilerin toplam vergi yükünün baskın bileşeni olduğu, hatta 1990'lı yılların ortalarından itibaren toplam vergi yüküne dolaylı vergi yükünün şekil verdiği rahatlıkla söylenebilir. Bu kapsamda çalışmada elde edilen analiz sonuçlarıyla birlikte değerlendirilecek olursa milli gelirde yaşanacak artışın 
daha çok dolaylı vergiler vasıtasıyla toplam vergi yükü üzerine bir yansıma gerçekleştirdiği ileri sürülebilir.

İktisadi büyüme ve kalkınma sürecine bağlı olarak ülkenin daha müreffeh bir sosyoekonomik ortama kavuşması, birey ve toplumun pek çok alışkanlığını, yaşam standardını ve iktisadi tercihlerini etkileyeceği gibi vergi ödeme gücü üzerinde de belirleyici olacaktır. Refah düzeyindeki (bu çalışma için milli gelir artışı) iyileşme, vergilendirilebilir kaynakların da beraberinde çoğalmasını sağlayarak vergi yükünün artmasını beraberinde getirecektir. Ancak teorik olarak beklenen, vergi yükündeki söz konusu artışın vergi kapasitesiyle sınırlı olacağıdır. Nihayetinde mali kapasitenin üzerinde bir vergi yükünün mevcudiyeti, vergileri iktisadi büyüme sürecini yavaşlatıcı bir unsur ve toplumdaki bireyler üzerinde ise memnuniyetsizlik kaynağı haline getirecektir. Ayrıca günümüz koşullarında maliye politikasının en önemli amaçlarından biri de gelir ve servet dağılımında adaletin sağlanmasıdır. Dolaysız vergilerin gelirin yeniden dağılımı açısından daha etkili bir mali araç olduğu ise teoride ortak kabul gören bir husustur. Çalışmada elde edilen bulgular, milli gelirdeki artışın vergi yükünü artırdığını göstermekle birlikte, özellikle 1990'lı yılların ortalarından itibaren vergi karması içerisinde dolaylı vergilerin daha baskın bir bileşen haline gelmesinin ve hatta toplam vergi yükünü yönlendirme gücünü bünyesinde barındırmasının, gelir dağılımı üzerinde yıpratıcı etkiler meydana getirdiği söylenebilir. Bu bağlamda vergi yükünün dengeli ve adil dağılımı ve gelir dağılımında adaletin tesis edilebilmesi için dolaysız vergi kapasitesinden optimal ölçekte yararlanacak politikaların üretilerek izlenmesi son derece önemlidir.

\section{References}

Açıkgöz, Ş. (2008), “Türkiye’de Vergi Gelirleri, Vergi Yapısı ve İktisadi Büyüme İlişkisi 19682006”, Ekonomik Yaklaşım, 19(68), 91-113.

Akbey, F. (2014), “Türkiye'de Vergi Denetimi ve Gelirleri Üzerine Bir İnceleme”, Dokuz Eylül Üniversitesi, İktisadi ve İdari Bilimler Fakültesi Dergisi, 29(1), 63-103.

Akdoğan, A. (2014), Kamu Maliyesi, Gazi Kitabevi, 16. Bask1, Ankara.

Albelo, C.D.A. (1999), "Complementarity between Physical and Human Capital, and Speed of Convergence", Economics Letters, 64(3), 357-361.

Arnold, J. (2008), "Do Tax Structures Affect Aggregate Economic Growth? Empirical Evidence from a Panel of OECD Countries”, Economics Department Working Papers, No: 643.

Bahl, R.W. (1971), “A Regression Approach to Tax Effort and Tax Ratio Analysis”, Staff Papers (International Monetary Fund), 18(3), 570-612, <http://doi.org/10.2307/3866315>, 25.11.2016.

Barro, R.J. (1991), "Economic Growth in A Cross Section of Countries", The Quarterly Journal of Economics, 104(2), 407-443.

Becker, G. \& K. Murphy \& R. Tamura (1990), "Human Capital, Fertility, and Economic Growth", Journal of Political Economy, 98(5), 12-37.

Becsi, Z. \& P. Wang (1997), "Financial Development and Growth", Economic Review, 82(4), 46-62.

Berksoy, T. (1984), “Gelişmekte Olan Ülkelerde Vergi Kapasitesi ve Vergi Gayreti”, Marmara Üniversitesi, Sosyal Bilimler Enstitüsü, Yayımlanmış Doktora Tezi, Yayın No: 411. 
Berksoy, T. \& İ. Demir (2004), "Politik Vergi Çevrimleri: Türkiye'de Vergi Yükü Üzerinde Politik Etkiler", 19. Türkiye Maliye Sempozyumu, Uludă̆ Üniversitesi, Belek-Antalya.

Bulut, Ş. \& S.H. Akdede (2013), "Türkiye'de Vergi Yükü ile Siyasi Eğilimler Arasındaki İlişki: Yatay-Kesit Analizi”, Finans Politik \& Ekonomik Yorumlar, 50(580), 95-109.

Cural, M. \& N.K. Çevik (2015), “Ekonomik Kalkınmanın Vergi Yapısı Üzerindeki Etkisi: 19242013 Dönemi Türkiye Örneği”, Amme İdaresi Dergisi, 48(3), 127-158.

Çelikkaya, A. (2002), “Mükelleflerin Vergiye Gönüllü Uyumunu Etkileyen Faktörler”, E-Akademi, 5, <http://www.e-akademi.org/makaleler/acelikkaya-1.htm>, 28.12.2016.

Çelikkaya, A. (2013), “OECD Üyesi Ülkelerde Emek Üzerindeki Vergi Yükünün Gelişimi ve Türkiye Üzerine Bir İnceleme”, TISK AKADEMI, 8(16), 68-91.

Demir, İ.D. (2013), Türkiye'de Vergi Yükü (Objektif ve Subjektif Yönleriyle), Bursa: Dora Yayınları.

Dennis, C. \& W.S. Moore \& T. Somerville (2007), "The Impact of Political Parties on the Distribution of State and Local Tax Burdens", The Social Science Journal, 44, 339-347.

Easterly, W. \& S. Rebelo (1993), "Fiscal Policy and Economic Growth", Journal of Monetary Economics, 32, 417-458.

Eltony, M.N. (2002), "Measuring Tax Effort in Arab Countries”, Working Paper 200229, Cairo: Economic Research Forum.

Engen, E. \& J. Skinner (1992), "Fiscal Policy and Economic Growth", NBER Working Paper, 4223, Cambridge, MA: National Bureau of Economic Research.

Erdoğan, E. \& M. Topçu \& O. Bahar (2013), "Vergi Gelirleri ve Ekonomik Büyüme İlişkisi: Türkiye Ekonomisi Üzerine Eşbütünleşme ve Nedensellik Analizi”, Finans Politik \& Ekonomik Yorumlar, 50(576), 99-110.

Ferhatoğlu, E. (2005), "Bir Kamu Harcaması Türü Olarak Vergi Harcaması ve Türk Kurumlar Vergisi Açısından Değerlendirilmesi”, Osmangazi Üniversitesi Sosyal Bilimler Dergisi, 6(2), 78-92.

Gelleny, R.D. \& M. Mccoy (2001), “Globalization and Government Policy Independence: The Issue of Taxation", Political Research Quarterly, 54, 509-529.

Grossman, M.G. \& E. Helpman (1989), "Product Development and International Trade". The Journal of Political Economy, 97(6), 1261-1283.

Gül, E. \& B. Kenar (2009), “AB Ülkeleri ve Türkiye’de Vergi Gelirleri ile Ekonomik Büyüme İlişkisi: 1980- 2008”, Uluslararası Davraz Kongresi 2009 Bildiri Kitabı, 16-26.

Işık, N. \& E.C. Kılınç (2009), “OECD Ülkelerinde Vergi Yükü ve Vergi Türleri: Karşılaştırmalı Bir Analiz”, KMU İ̈BF Dergisi, 11(17), 147-174.

Jones, L.E. \& R.E. Manuelli \& P.E. Rossi (1993), "Optimal Taxation in Models of Endogenous Growth", Journal of Political Economy, 101(3), 485-517.

Karagianni, S. \& M. Pempetzoglou \& A. Saraidaris (2012), “Average Tax Rates and Economic Growth: A NonLinear Causality Investigation for the USA", Frontiers in Finance and Economics, 12(1), 51-59.

Koester R.B. \& R.C. Kormendi (1989), “Taxation, Aggregate Activity and Economic Growth: Cross Country Evidence on Some Supply Side Hypotheses", Econ Inq, 27, 367-387.

Kong, S. \& M.P. Hoek (2008), "Is the Growth of Chinese Annual Tax Revenues Unnatural?", Journal of Public Budgetting, Accounting \& Financial Management, 20 (4), 554-570. 
Kuştepeli, Y. \& M. Bilman, (2009), “Türkiye'de Vergiler ve Büyüme Arasındaki Uzun Dönem İlişkisi”, İsletme Fakültesi Dergisi, 10 (1), 119-130.

Leibfritz, W. \& J. Thornton \& A. Bibbee (1997), "Taxation and economic performance, Organization for Economic Co-operation and Development”, Working Paper 176.

Liu, Y. \& H. Feng (2015), “Tax Structure and Corruption: Cross-Country Evidence”, Public Choice, $162,57-78$.

Lotz, J.R. \& E.R. Morss (1967), "Measuring Tax Effort in Developing Countries”, International Monetary Staff Papers, 14, 479-497.

Lucas, E.R. (1988), "On the Mechanics of Economic Development”, Journal of Monetary Economics, 22(1), 3-42.

Mangır, F. \& H.M. Ertuğrul (2012), "Vergi Yükü ve Ekonomik Büyüme İlişkisi: 1988-2011 Türkiye Örneği”, Maliye Dergisi, 162, 256-266.

Nadaroğlu, H. (1978), Kamu Maliyesi Teorisi, Sermet Matbaası, 3. Bask1, İstanbul.

Nikola, S. (2015), “The Hierarchical Clustering of Tax Burden in the EU27”, Journal of Competitiveness, 7(3), 95-109.

Öztürk, İ, \& A. Ozansoy (2011), “Ücret Gelirleri Üzerindeki Vergi Yükünün Analizi”, Maliye Dergisi, 161, 197-215.

Pesaran, M.H. \& Y. Shin \& R. Smith (1996), "Testing for the Existence of a Long-Run Relationship", University of Cambridge, DAE Working Paper, No. 9622.

Pesaran, M.H. \& R. Smith (1998), "Structural Analysis of Cointegrating VARs", Journal of Economic Survey, 12(5), 471-505.

Pesaran, M.H. \& Y. Shin (1999), “An Autoregressive Distributed Lag Modeling Approach to Cointegration Analysis", in: S. Storm (Ed.), Econometrics and Economic Theory in the 20th Century, The Ragnar Frish Centennial Symposium, Cambridge University Press.

Pesaran, M.H. \& Y. Shin \& R.J. Smith (2001), "Bound Testing Approaches to the Analysis of Level Relationships", Journal of Applied Econometrics, 16, 289-326.

Purohit, M. (2006), "Tax Efforts and Taxable Capacity of Central and State Governments", Economic and Political Weekly, 747-754.

Rebelo, S. (1991), “Long-run Policy Analysis and Long-Run Growth”, The Journal of Political Economy, 99(3), 500-521.

Reed, W. (2006), "Democrats, Republicans, and Taxes: Evidence That Political Parties Matter", Journal of Public Economics, 90, 725-750.

Romer, P. (1986), “Increasing Returnsand Long-run Growth”, Journal of Political Economy, 94(5), 1002-1037.

Romer, P. (1990), "Endogenous Technological Change”, The Journal of Political Economy, 98(5), 71-102.

Shin, K. (1969), "International Difference in Tax Ratio", Review of Economics and Statistics, 51, 213-220.

Slemrod J. \& S. Yitzhaki (1995), "The Costs of Taxation and the Marginal Cost of Funds", IMF Working Paper, 83.

Stotsky, J.G. \& W. Asegedech (1997), "Tax effort in Sub-Saharan Africa”, IMF Working Paper, 107. 
Tekbaş, A. \& G. Dökmen (2007), “Türkiye'de Vergi Yükünün Bölgesel Dağılımı”, Maliye Dergisi, $153,195-214$.

Temiz, D. (2008), “Türkiye'de Vergi Gelirleri ve Ekonomik Büyüme İlişkisi: 1960-2006 Dönemi”, 2. Ulusal İktisat Kongresi, İzmir.

Thorn, R.S. (1967), “The Evolution of Public Finances during Economic Development”, The Manchester School, 35, 19-53; doi: 10.1111/j.1467-9957.1967.tb01204.x.

Tiwari, A.K. \& M. Mutascu (2014), "A Revisit on The Tax Burden Distribution and GDP Growth: Fresh Evidence Using a Consistent Nonparametric Test For Causality for The USA", Empirical Economics, 46, 961-972.

Truong, T.V. \& D.N. Gash (1979), "Less-Developed Countries' Taxable Capacity and Economic Integration: A Cross-Sectional Analysis", The Review of Economics and Statistics, 61(2), 312-316, <http://doi.org/10.2307/1924603>.

Uluatam, Ö. (1997), Kamu Maliyesi, İmaj Yayınevi, 5. Baskı, Ankara.

Ünlükaplan, İ. \& İ. Arısoy (2011), "Vergi Yükü ve Yapısı ile İktisadi Büyüme Arasındaki Dinamik Etkileşimler Üzerine Uygulamalı Bir Analiz”, ODTÜ Gelişim Dergisi, 38 (Nisan), 71100.

Vasiliauskaite, A. \& E. Stankevicius (2009), "Tax Burden Management and GDP Growth: Case of EU Countries”, Economics \& Management, 2009(14), 202-211. 


Yazarlar
J.G.Stotsky
W.Asegedech
(1997)
Ronald D. Gelleny
Matthew McCoy
(2001)
W. Robert Reed
(2006)
Christopher Dennis
William S. Moore
Tracey Somerville
(2007)

Senay Açıkgöz
(2008)

Shuhong Kong
M. Peter van der
Hoek (2008)
Asta Vasiliauskaite
Evaldas
Stankevicius
$(2009)$

$\begin{array}{ll}\text { İlter Ünlükaplan } & \text { Türkiye } \\ \text { İbrahim Arısoy } & \text { 1968-2006 Dönemi } \\ \text { (2011) } & \text { yıllık }\end{array}$

\section{Stella Karagianni,}

Maria

Pempetzoglou,

Anastasios

Saraidaris (2012)

F. Mangir

H.M. Ertuğrul

(2012)

Şahin Bulut

Sacit Hadi Akdede

(2013)

\section{E. Erdoğan}

M. Topçu

O. Bahar

(2013)

Yongzheng Liu

Haibo Feng

(2015)

Mehmet Cural

Nüket Kırcı Çevik

(2015)
Veri Seti

43 Afrika ülkesi

1990-1995

yillık

17 OECD üyesi ülke

1982-1991

yillik

ABD (45 eyalet)

1960-2000 dönemi Panel OLS

y1llik

ABD

Türkiye

1968-2006 Dönemi

Yillik

Çin

1984-2004 dönemi

yillik

$\mathrm{AB}$ üyesi ülkeler

1995-2007 dönemi

y1llik

ABD 1964:

1.Çeyrek-2007:

2.ÇeyrekÇeyrek

dönemlik veriler

Türkiye

1988-2011

yıllık

Türkiye

(il merkezleri)

"1987, 1991,

1995, 1999"

Genel Seçimleri

Türkiye

1998-2011

(çeyrek dönem)

150 ülke

1995-2009

y1llik

Türkiye
1924-2013
y1llık

Panel OLS

Granger

Spearman

kümeleme

analizi

Analizleri

Doğrusal

olmayan

nedensellik

analizi

Analizi ve

Analizleri, modeli

Panel OLS

OLS

Parçalı

regresyon

\section{EK: 1}

\section{Literatür Özeti}

Yöntem Kullanılan Değişkenler

Tarım-madencilik-sanayi sektörler

payı, ihracat ve ithalat payı, kişi başına

düşen gelir, zaman etkileri gösteren

kukla değişkenleri

Kurumlar Vergisi, Eğitim ve Araștırma Programları, Dışa açıklık, Küresel sermaye akımları

Siyasi partiler, Seçmenlerin ve eyaletlerin karakteristikleri, Birincil vergi yükü

Merkezi ve yerel vergilerin gelir gruplarına göre oranı, Uygulanan kamu

Yatay kesit OLS politikası ve siyasi düşünceler, Demokratik sahiplik derecesi, gelir eşitsizliği, Gelir vergisi, Satış vergileri Reel GSYİH büyüme hızı, Yurtiçi Tasarruflar/GSYİH, Sabit sermaye nedensellik ve VAR Analizi birikimi/GSYİH, Dolaylı vergiler/Vergi gelirleri, Dolaysız Vergiler/vergi gelirleri, toplam vergi yükü, dolaylı vergi yükü, dolaysız vergi yükü

Lineer regresyon Vergi hasılatı ve Gayri Safi Yurt İçi ARCH modeli Hâsıla

korelasyon ve

GSYİH, vergi yükü, ekonomik büyüme, vergi sistemleri

Eşbütünleşme ve Vergi yükü (dolaylı ve dolaysız vergi

Nedensellik yükü), Dolaylı vergiler/dolaysız vergiler, ekonomik büyüme

Eşbütünleşme

ARDL Yöntemi

Yatay kesit OLS

GSYİH, ekonomik büyüme, ortalama vergi oranı

\section{Vergi yükü, GSYİH}

Vergi yükü (tahakkuk), Vergi yükü (tahsilat), İllere göre kişi başına gelir (Dolar), Nüfus, Sağ siyasi partilerin oy oranları ortalamaları, Sol siyasi partilerin oy oranları ortalamaları, Oy farkı, Bölgeler

Eşbütünleșme ve

Nedensellik

Hata düzeltme

Zaman serisi
Dolaylı, dolaysız, toplam vergi gelirleri, GSYİH

Yolsuzluk indeksleri, Vergi karması, vergi ödemeleri, GSYİH, Nüfus, Dışa açıklık, Demokrasi, Kamu kesimi büyüklüğü, beșeri sermaye, Enflasyon, kukla değişkenler.

Dolayl1-Dolaysız vergiler, gelir üzerinden alınan vergiler, mal ve hizmetler üzerinden alınan vergiler, servet ve dış ticaret üzerinden alınan vergiler, Kişi başına GSYİH
Analiz Sonuçları

Vergi yükünü tarım-madencilik sektörlerinin negatif, ihracat payı ile kişi başına gelirin pozitif yönde etkilediğ tespit edilmiştir.

Dışa açıklık kurumlar vergisi oranını pozitif yönde etkilemektedir. Ayrica eğitim hizmetleri ile kurumların vergilendirmesi arasında da ilişki bulunmaktadır.

Demokratların meclis ve senatoda daha fazla söz hakkına sahip olduğu dönemlerde vergi yükü artmaktadır. Yüksek ve düşük gelir grupları üzerindeki yerel vergi yükleri ele alınmıştır. Sosyal demokratların iktidar olduğu dönemlerde düşük gelirliler üzerindeki vergi yükü azalmaktadır.

Dolaysız vergi gelirlerinin GSYİH içerisindeki payı düşük ise daha yüksek bir büyüme oranı sağlanmaktadır.

GSYİH'da meydana gelen artışlar vergi hasılatını artırmaktadır.

GSYİH'daki artış ile vergi yükü arasında yüksek korelasyon bulunmaktadır.

Kısa dönem: iktisadi büyüme $\Rightarrow>$ verg kaması, uzun dönem: iktisadi büyüme ile vergi kaması =>vergi yükü, Vergi kaması ile vergi yükü $=>$ iktisadi büyüme

Vergi yükünden ekonomik büyümeye doğru nedensellik ilişkisi saptanmıştır. Yine refah artışı da vergi yükünde ve vergilerin yeniden dağılımı üzerinde etkili olmaktadır.

Uzun ve kısa dönemde vergi yükü ile GSYİH arasında istatistiksel olarak ters yönlü bir ilişki vardır.

İllerin kişi başına gelirleri ile vergi yükü arasında ters yönlü ilişki vardır. Sağ ideolojiye sahip siyasi partilerin oy oranlarının göreceli olarak daha fazla olduğu illerde vergi yükünün daha düşük seviyede gerçekleşmektedir. Dolaylı vergiler ile ekonomik büyüme arasında uzun dönemli bir ilişki vardır. Kısa ve uzun dönemde $=>$ Dolaylı vergi gelirlerinden ekonomik büyümeye doğru tek yönlü nedensellik vardır.

Vergi sisteminde dolaylı vergilerin ağırlığının artması durumunda vergi yükünün daha az hissedilir olacak, yolsuzluk potansiyeli düşecektir.

Kişi başına düşen GSYİH'nın gelir üzerinden alınan vergiler, mal ve hizmetler üzerinden alınan vergiler ile dış ticaret işlemlerinden alınan vergiler üzerinde istatistiksel olarak anlamlı ve olumlu bir etkisi vardır. 